\title{
sciendo
}

\author{
EDYTA GAŁĘZIOWSKA ${ }^{1}$, KAROLINA KICIŃSKA², \\ ZDZISŁAWA SZADOWSKA-SZLACHETKA'1 , RENATA DOMŻAŁ-DRZEWICKA ${ }^{1}$
}

\section{Assessment of the risk of postpartum depression and the support expected and received by women within a year of giving birth}

\begin{abstract}
Introduction. Postpartum depression (post-natal depression, pure postpartum depression, $P P D$ ) is one of three types of postnatal mood disorders. The degree (severity) of this disorder may be defined as moderate or severe. A milder form of depression is postpartum sadness (baby blues), while the untreated depression can develop into a very severe form of depression called postpartum psychosis

Aim. The aim of the work was to analyse the incidence and severity of postpartum depression symptoms in women in the first year after giving birth, evaluated by the Edinburgh Postnatal Depression Scale, and the social support received and expected by them.

Material and methods. This paper presents the severity of depressive symptoms in 150 women measured by the Edinburgh Postnatal Depression Scale in the first year after their giving birth as well as the support received by them and the demand for it.

Results. More than half of the women filling in the Edinburgh Postnatal Depression Scale achieved a result indicating a high risk of postpartum depression (more than 12 points). The severity of postpartum depression symptoms depended on the place of residence of women, was related to attendance antenatal classes, breastfeeding and the support received.

Conclusions. It would be advisable to initially assess the risk of postpartum depression in women immediately after childbirth and the social support available to them.
\end{abstract}

Keywords: postpartum depression, Edinburgh Postnatal Depression Scale, social support.

DOI: $10.2478 /$ pjph-2021-0012

\section{INTRODUCTION}

Postpartum depression is a mood disorder experienced by a woman after the birth of a child. According to both DSM-IVTR and ICD-10 classifications, postpartum depression occurs within the first six weeks after giving birth [1]. However, many clinicians and researchers in this field stress that an episode of postpartum depression may occur within the first year after giving birth [2]. A prerequisite for the diagnosis of depression is that the symptoms of this emotional disorder persist for at least fourteen days [3]. It is a disorder of heterogeneous origin, which means that it is conditioned mainly by psychological and social factors and partly by personality factors [4]. Risk factors of postpartum depression can be divided into 4 groups: variable demographic factors, biological, psychological and social factors, as well as gynaecological and obstetric factors [5].
AIM
The aim of the work was to analyse the incidence and se- verity of postpartum depression symptoms in women in the first year after giving birth, evaluated by the Edinburgh Post- natal Depression Scale, and the social support received and expected by them.

\section{MATERIAL AND METHODS}

The study was carried out on a sample of 150 women. The average age of the women was 28 years. The youngest respondent was 18 years old, while the oldest was 41 years old. More than half of the women $-58.70 \%$ had higher education, $38 \%$ had secondary or vocational education, $3.30 \%$ had primary or lower secondary education. Marital status: $96 \%$ were married or in informal relationship, $4 \%$ of women were unmarried.

The most numerous group were city residents $-66 \%$, suburban areas were inhabited by $25.30 \%$ of women, while rural areas were inhabited by $8.70 \%$ of mothers. Women, who were six months after giving birth, constituted more than a half of the surveyed $-55.3 \%, 25.3 \%$ were in the period from the fourth to the sixth month after giving birth, $18.7 \%$ of mothers gave birth to a child within the last 1-3 months.

When it comes to $18 \%$ of women - i.e. almost one in five indicated that she suffered from postpartum depression or other mental disorders after the previous childbirth(s). More than half $(58.70 \%)$ of the studied group was in a good financial situation; $10.7 \%$ were in a very good financial situation; $27.30 \%$ were financially stable and $3.30 \%$ were in a bad financial situation. About one in three respondents $(35.3 \%)$ recalled her giving birth as traumatic, $29.3 \%$ said that it was a painful experi-

\footnotetext{
${ }^{1}$ Department of Oncology and Environmental Health, Faculty of Health Science, Medical University of Lublin, Poland

${ }^{2}$ Graduate of Medical University of Lublin, Poland
} 
ence; only less than $17 \%$ of women considered childbirth as the most beautiful experience, $18.7 \%$ had no opinion about it. According to the majority of the respondents $-90 \%$, childbirth was normal, in case of $10 \%$ of women it was complicated. In this work the diagnostic survey method was used, the research technique was an interview, while the research tool was the author's questionnaire and the sheet of Edinburgh Postnatal Depression Scale by John L. Cox, Jenifer M. Holden and Ruth Zagorsky.

The Edinburgh Postnatal Depression Scale (EPDS) is a set of 10 questions about a woman's well-being in terms of the past seven days. Each question is followed by four answers evaluated with a score from 0 to 3 points, which gives a maximum of 30 points. Women who score 12 or more points are likely to face postpartum depression of varying degrees of severity [6].

The statistical program PQstat Software was used to calculate the test results. The values are presented in percentage categories. The Chi 2 test was used to detect dependencies between the compared groups. The value of $p<0.05$ was assumed for the significance level.

\section{RESULTS}

In the study group of 150 women in the first year after childbirth, just over half of the women had a score of 12 or more points according to the Edinburgh Postnatal Depression Scale, which may indicate the possibility of postpartum depression in these mothers with varying degrees of symptom intensification - Fig. 1.

Frequency and severity of postpartum depression according to EPDS

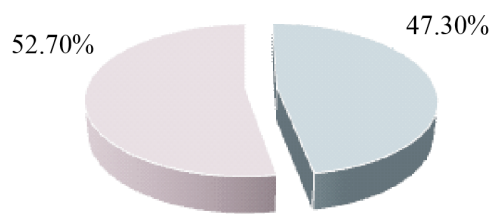

II women with a score of 11 or less

women with a score of 12 or more

FIGURE 1. Frequency and severity of postpartum depression according to EPDS.

Figure 2 presents respondents' answers to question 10 of the Edinburgh Postnatal Depression Scale, which shows that almost one fifth of the respondents $(22.70 \%)$ answered affirmatively (yes, quite often and sometimes) to the question on the willingness to harm themselves, which should be a signal for an urgent assessment of their mental health by a specialist.

Question 10 (EPDS): The thought of harming myself has occurred to me.

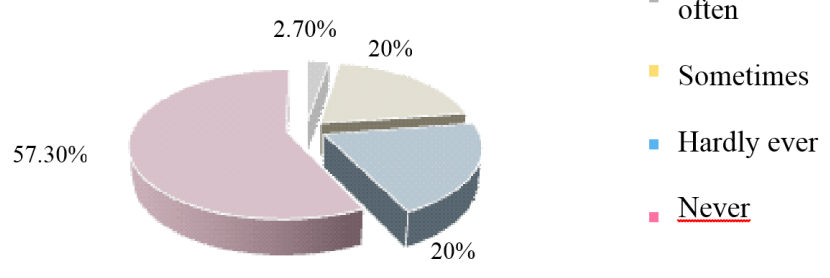

According to the EDPS's study, women most often pointed to reduced wellbeing (96\% - question 8) and feelings of guilt (96\% - question 3), sleep problems (84.7\% - question 7) and worries and anxieties ( $84 \%$ - question 4$)$, willingness to harm themselves (42.7\% - question 10), crying (question $9-66 \%$ ), inability to rejoice (question $2-62.7 \%$ ) and inability to perceive positives (question $1-54 \%$ ), horror and panic (question $5-42 \%$ ) - see Figure 3 .

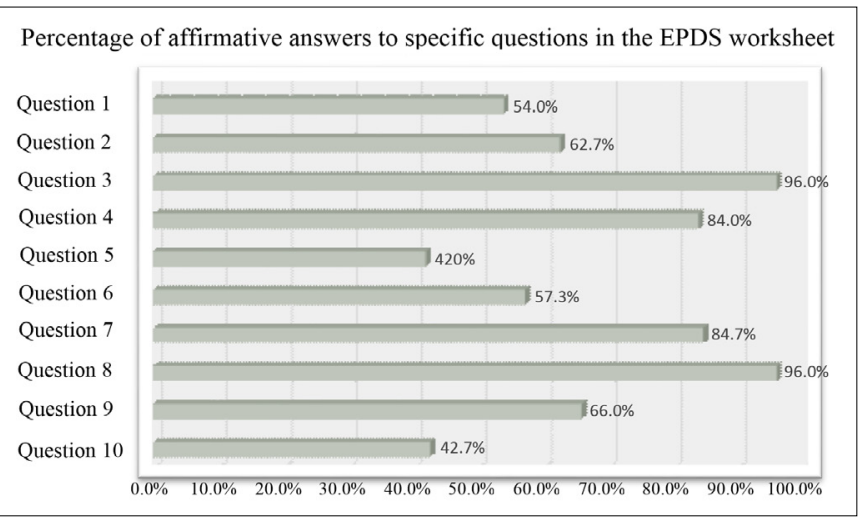

FIGURE 3. Percentage of affirmative answers to specific questions in the EPDS worksheet.

A statistically significant correlation between the place of residence and the financial situation of the studied women and the results obtained by them on the EPDS scale was shown. The majority of women living in rural areas scored 11 points or less on the EPDS scale, which indicates a lower risk of postpartum depression, while women living in urban and suburban areas received 12 or more points. All mothers who assessed their financial situation as bad received 12 points indicating the possibility of postpartum depression. Women who attended antenatal classes went through postpartum depressive disorders more mildly than mothers who did not use this form of preparation for motherhood $-\mathrm{p}<0.01$. Childbirth, which turned out to be a painful or traumatic experience for women, was associated with the scoring indicating a severe postpartum depression, in contrast to mothers for whom childbirth was the most beautiful experience or mothers who have no opinion on the subject $-\mathrm{p}<0.001$.

\section{Risk of postpartum depression and social support in the} study group

The vast majority of respondents $(84 \%)$ declared the need for support, while $16 \%$ of the respondents negated this need. The relationship between the sources of support used by women and the number of points that may indicate postpartum depression (EPDS) is shown in Table 1. Statistical significance was found in the selection of support sources (psychologist / psychotherapist, support groups, and other sources) in relation to the number of points obtained in the postnatal depression scale. It was found that respondents with scores of 12 and more often sought help from a psychologist or psychotherapist $(75 \%)$ and in support groups $(63.7 \%)$ and used sources of social support other than those mentioned above (76.2\%) as compared to respondents with lower EPDS scores (11 and fewer points) - Table 1 . 
TABLE 1. The relationship between the sources of support most frequently used by women with postpartum depression and the number of points obtained according to the Edinburgh Postnatal Depression Scale (EPDS).

\begin{tabular}{|c|c|c|c|c|c|c|}
\hline & \multicolumn{3}{|c|}{ Results according to EPDS } & \multicolumn{3}{|c|}{ Chi-square test } \\
\hline & & $\begin{array}{l}11 \text { and } \\
\text { less }\end{array}$ & $\begin{array}{l}12 \text { and } \\
\text { more }\end{array}$ & $\chi^{2}$ & df & $\mathbf{p}$ \\
\hline \multirow{9}{*}{ 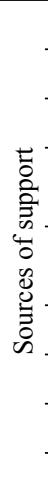 } & Midwife & $49.5 \%$ & $50.5 \%$ & 0.51 & 1 & 0.48 \\
\hline & Physician & $48.3 \%$ & $51.7 \%$ & 0.16 & 1 & 0.69 \\
\hline & Psychologist/ psychotherapist & $25 \%$ & $75 \%$ & 30.82 & 1 & $<0.001$ \\
\hline & $\begin{array}{c}\text { Municipal Family Support } \\
\text { Centre }\end{array}$ & $44.4 \%$ & $55.6 \%$ & 0.07 & 1 & 0.79 \\
\hline & $\begin{array}{c}\text { Municipal Social Services } \\
\text { Centre }\end{array}$ & $50 \%$ & $50 \%$ & 0.07 & 1 & 0.8 \\
\hline & Spiritual groups & $30 \%$ & $70 \%$ & 2.78 & 1 & 0.09 \\
\hline & Support groups & $36.3 \%$ & $63.7 \%$ & 8.45 & 1 & 0.004 \\
\hline & Internet & $42.7 \%$ & $57.3 \%$ & 2.8 & 1 & 0.09 \\
\hline & Other & $23.8 \%$ & $76.2 \%$ & 6.48 & 2 & 0.04 \\
\hline
\end{tabular}

Women who stated that they could not count on support from any of their loved ones received a significantly higher (12) EPDS score - Table 2.

TABLE 2. The relationship between the declared support of a loved one and the number of points obtained according to the Edinburgh Postnatal Depression Scale (EPDS).

\begin{tabular}{|c|c|c|c|c|c|c|}
\hline & \multicolumn{3}{|c|}{ Results according to EPDS } & \multicolumn{3}{|c|}{ Chi-square test } \\
\hline & & $\begin{array}{c}11 \text { and } \\
\text { less }\end{array}$ & $\begin{array}{c}12 \text { and } \\
\text { more }\end{array}$ & $\chi^{2}$ & df & $\mathbf{p}$ \\
\hline \multirow{5}{*}{ 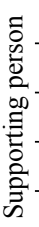 } & Husband/partner & $54.8 \%$ & $45.2 \%$ & 14.83 & 4 & 0.005 \\
\hline & Mother/father & $45 \%$ & $55 \%$ & & & \\
\hline & Sister/friend & $60 \%$ & $40 \%$ & & & \\
\hline & Other person & $14.3 \%$ & $85.7 \%$ & & & \\
\hline & Lack of support & $7.1 \%$ & $92.9 \%$ & & & \\
\hline
\end{tabular}

Table 3 shows the relationship between the type of support needed by women and the number of points obtained according to the Edinburgh Postnatal Depression Scale (EPDS). The following statistically significant dependence was found: mothers who scored 12 or more in EPDS scale definitely needed more mental support $(86.7 \%)$ and help or replacement in childcare. Women with lower EPDS scores (11 and less points) more often indicated the need for in-kind support $(66.7 \%)$, presence of another person (66.2\%) and information support from medical staff $(60 \%)$ - Table 3 .

TABLE 3. The relationship between the type of support needed by women and the number of points obtained according to the Edinburgh Postnatal Depression Scale (EPDS).

\begin{tabular}{|c|c|c|c|c|c|c|}
\hline & \multicolumn{3}{|c|}{ Results according to EPDS } & \multicolumn{3}{|c|}{ Chi-square test } \\
\hline & & $\begin{array}{l}11 \text { and } \\
\text { less }\end{array}$ & $\begin{array}{l}12 \text { and } \\
\text { more }\end{array}$ & $\chi^{2}$ & df & $\mathbf{p}$ \\
\hline \multirow{5}{*}{ 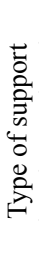 } & In-kind support & $66.7 \%$ & $33.3 \%$ & 26.74 & 4 & $<0.001$ \\
\hline & Mental support & $13.3 \%$ & $86.7 \%$ & & & \\
\hline & $\begin{array}{c}\text { Information } \\
\text { from midwife/ physician }\end{array}$ & $60 \%$ & $40 \%$ & & & \\
\hline & Presence of another person & $66.2 \%$ & $33.8 \%$ & & & \\
\hline & Help/replacement in childcare & $35.9 \%$ & $64.1 \%$ & & & \\
\hline
\end{tabular}

Table 4 presents the relationship between asking for help when a woman needs it and the number of points obtained according to the Edinburgh Postnatal Depression Scale. Here we can also see a significant statistical correlation - respondents who obtained 12 or more points on EPDS scale were much less likely to ask for help when they needed it (only $32.7 \%$ ) compared to women who obtained a lower number of points on this scale - here $67.3 \%$ of the respondents answered affirmatively - Table 4.

TABLE 4. The relationship between asking for help when a woman needs it and the number of points obtained according to the Edinburgh Postnatal Depression Scale (EPDS).

\begin{tabular}{cccccccc}
\hline & Results according to EPDS & \multicolumn{3}{c}{ Chi-square test } \\
\hline & & $\begin{array}{c}\mathbf{1 1} \text { and } \\
\text { less }\end{array}$ & $\begin{array}{c}12 \text { and } \\
\text { more }\end{array}$ & $\boldsymbol{\chi}^{2}$ & df & p \\
\hline & Yes & $67.3 \%$ & $32.7 \%$ & 13.85 & 1 & $<0.001$ \\
\hline
\end{tabular}

\section{DISCUSSION}

The studies covered the assessment of postpartum depression risk measured by the Edinburgh Depression Scale and aimed to determine the factors influencing its occurrence. A further objective of the study was to identify available sources of support for women in postpartum period in relation to the support received and the expressed demand for the support as well as the impact of the support on the severity of depressive symptoms as measured by EPDS.

Postpartum depression is a phenomenon that increasingly affects women after childbirth. According to Borysiewicz [7], these symptoms may appear from a few weeks after childbirth even up to a year after childbirth and the number of obtained points exceeding twelve $(>12)$ is assumed to be a significant aggravation of depression. According to the conducted studies, more than half of women $(52.7 \%)$ obtained such a high result. To question 10 of the Edinburgh Postnatal Depression Scale, concerning the willingness to harm oneself - a large percentage of women $(22.7 \%)$ answered affirmatively, which should be a signal for an urgent evaluation by a specialist, even if the total number of points obtained on this scale does not indicate the risk of severe aggravation of postpartum depressive disorders. The studies of Maliszewska et al. showed that postpartum depression affected less than 7\% of 548 women [8].

Other studies by this author (Maliszewska et al.) showed that $15.85 \%$ of the respondents were affected by mood disorders [9]. These studies showed that a higher risk of postpartum depressive disorders is observed in mothers living in urban and suburban areas and in those who have not breastfed. Breastfeeding as a protective factor against depression is also indicated by other researchers such as Deniss, Figueiredo et al., Hatton et al. [10-12].

Dudek et al. also indicate the aspect of unsuccessful breastfeeding as an important risk factor of postpartum depression [13], while the study by Alici-Evcimen showed that this variable does not affect the severity of postpartum depression symptoms [14]. It was also shown that women attending antenatal classes during pregnancy declared much lower severity of depressive symptoms than women who did not participate in this form of preparation for childbirth and childcare. A statistically significant correlation was also obtained, which 
shows that the more significant the patient's history of earlier episodes of mental disorders, the greater the severity of postnatal depression symptoms. The same correlation is observed in the case of bad financial situation of women and in the absence of support of the loved ones.

Kosińska-Kaczyńska et al. mention also a significant history of mental disorders, low socio-economic status and lack of help from the loved ones as risk factors for postpartum depressive disorders. The same authors showed in their studies that the place of residence and the aspect of breastfeeding have no statistically significant impact on the occurrence of postpartum depression symptoms [3].

The results of this study show that the most frequent symptoms of postpartum depression were: reduced mood $(96 \%)$, feelings of guilt (96\%), sleep problems $(84.7 \%)$ and worries and anxieties (84\%). Fejfer-Szpytko et al. indicate depressed mood, fatigue, lack of energy as well as loss of interest as the most frequent and most important symptoms of postpartum depression [15]. Study of Małus et al. showed no correlation between the occurrence of postpartum depression and sociodemographic factors, while women dissatisfied with the quality of their marriage experienced intensification of postpartum depression symptoms. Greater satisfaction with the quality of relationships was expressed by women in formalised relationships [17].

According to studies by Maliszewska et al., a high level of neuroticism and introversion, as well as a greater fear of childbirth and the need for social support were factors that increased the probability of mood disorders in the early period [9]. Studies on women in Iran conducted by Cheraghi et al. showed a significant relationship between the mother's age, education, satisfaction with the newborn child's sex as well as the method of childbirth and the postpartum depression $(p<0.5)$ [17].Our own studies show that the vast majority of women use social support of their loved ones. However, women who scored 12 or more points on EPDS scale were more likely to choose a psychologist or psychotherapist and support groups, rather than their loved ones, as a source of help. Women who reported that they did not receive support from their closed ones were statistically significantly more likely to have a score above 12 on EPDS scale.

It was also found that the vast majority of women with a high score (12 points) on EPDS scale expected mental support, while those who received less than 11 points on EPDS scale expected in-kind and information support. The surveyed women indicated informal support received from their husband/partner, friends, parents, sister, friend. According to Kossakowska, women with symptoms of postpartum depression were most likely to count on the support of their husband/partner and midwife [5]. Studies conducted by Małus et al. show that women who declared greater satisfaction with their relationship showed a better mental well-being after the birth of a child. In their subjective perception, their partners responded in a more coherent way, similar to their own, showed greater closeness and understanding, and responded more comprehensively to their needs compared to women who were dissatisfied with their relationship [16].

Burke, on the other hand, showed a connection between disharmony, incompatibility and marital conflicts and depressive symptoms [18]. Studies by Gremigni et al. also show that women who assessed the support of their partners as not meeting their own expectations, experienced at the same time a greater intensity of postpartum depression symptoms, as measured by the Edinburgh Depression Scale [19]. Similarly, Page and Wilhelm showed a relationship between the severity of postpartum depressive symptoms measured by CES-D (Centre for Epidemiological Studies Depression Scale) and the support received in a marital relationship. They also documented the relationship between the severity of postpartum depression symptoms and the depth of the marital relationship, understood as perceiving the relationship as positive, important and safe [20]. Maliszewska et al. state that a special type of social support received immediately after the childbirth and giving real satisfaction, can have a positive impact on the mood of patients. On the other hand, when a woman protects others from bad information and pretends to be strong and doing well, the risk of depression increases [8].

\section{CONCLUSIONS}

1. In the study using Edinburgh Postnatal Depression Scale, more than half of the women obtained a score indicating the possibility of postpartum depression and more than one fifth of the respondents answered affirmatively to the question concerning their willingness to harm themselves, which may indicate the need to provide professional help to these people.

2. Symptoms indicating postpartum depression were more frequent in women who did not attend the antenatal classes, did not breastfeed, had bad financial status and faced difficult circumstances concerning childbirth.

3. A higher risk of postpartum depression occurs in women without natural sources of support (husband, parents, sister, friend).

4. It would be advisable to carry out screening tests to detect the symptoms of postpartum depression in women within the first year after giving birth in order to identify women in need of help and then to provide them with this help.

\section{Conflicts of interest}

This study received no funding, and the authors have no conflicts of interest to declare.

\section{REFERENCES}

1. Pużyński S, Wciórka J. Klasyfikacja zaburzeń psychicznych i zaburzeń zachowania w ICD-10. Kraków-Warszawa: Uniwersyteckie Wydawnictwo Medyczne Vesalius; 2000.

2. Nylen K, Moran T, Franklin C, O’Hara M. Maternal depression: A review of relevant treatment approaches for mothers and infants. Inf Ment Health J. 2006;27:327-43

3. Kosińska-Kaczyńska K, Horosz E, Wielgoś M, Szymusik I. Zaburzenia afektywne u położnic w pierwszym tygodniu po porodzie - analiza rozpowszechnienia i czynników ryzyka. Ginekol Pol. 2008;79(3):182-5.

4. Kossakowska K. Kwestionariusz rozpoznawania objawów depresji poporodowej - polska adaptacja i psychometryczna ocena kwestionariusza Postpartum Depression Screening Scale (PDSS). Postępy Psychiatr Neurol. 2012;21(2):123-9.

5. Kossakowska-Petrycka K, Walęcka-Matyja K. Psychologiczne uwarunkowania wystąpienia depresji poporodowej u kobiet w ciąży o przebiegu prawidłowym i ciąży wysokiego ryzyka. Ginekol Pol. 2007;78(7):544-8.

6. Chrzan-Dętkoś M, Dyduch-Maroszek A. Humięcka A, et al. Uwarunkowania i konsekwencje depresji poporodowej. Psychoterapia. 2012; 2(161):55-63

7. Borysiewicz K. Edynburska Skala Depresji poporodowej. Postępy Psychiatr Neurol. 2000;(9):71-7. 
8. Maliszewska K, Swiątkowska-Freund M, Bidzan M, et al. Ryzyko depresji poporodowej a cechy osobowości i wsparcie społeczne. Polskie przesiewowe badanie obserwacyjne matek 4 tygodnie i 3 miesiace po porodzie. Psychiatr Pol. 2017;51(5):889-98.

9. Maliszewska K, Bidzan M, Świątkowska-Freund M, et al. Personality type, social support and other correlates of risk for affective disorders in early puerperium. Ginekol Pol. 2016;87(12):814-9.

10. Dennis C-L, McQueen K. The relationship between infant-feeding outcomes and postpartum depression: a qualitative systematic review. Pediatrics. 2009;123(4):736-51.

11. Figueiredo B, Dias CC, Brandao S, et al. Breastfeeding and postpartum depression: state of the art review. J Pediatr (Rio J). 2013;89(4):332-8.

12. Hatton DC, Harrison-Hohner J, Coste S, et al. Symptoms of postpartum depression and breastfeeding. J Hum Lact. 2005;21(4):444.

13. Dudek D, Siwek M, Zięba A. Depresja poporodowa. Prz Lek. 2002;59:919. 23.

14. Alici-Evcimen Y, Sudak D. Postpartum depression. Primary Care Update for Ob/Gyns. 2003;10:210-6.

15. Fejfer-Szpytko J, Włodarczyk J, Trąbińska-Haduch M. Rozpoznanie sytuacji matek małych dzieci w temacie depresji poporodowej i zaburzeń nastroju. Dziecko Krzywdzone: Teoria, Badania, Praktyka. 2016;15(3):91116.

16. Małus A, Szyluk J, Galińska-Skok B, et al. Występowanie depresji poporodowej a jakość relacji w związku. Psychiatr Pol. 2016;50 (6):1135-46.

17. Cheraghi M, Najafian M, Amoori N, et al. Risk factors of postpartum depression in Ramhormoz city, Iran. Neuropsychiatr Neuropsychol. 2015;10(1):1-4.

18. Burke L. The impact of maternal depression on familial relationships. Int Rev Psychiatr. 2003;15(3):243-55.

19. Gremigni P, Mariani L, Marracino V, et al. Partner support and postpartum depressive symptoms. J Psychosom Obstet Gynecol. 2011;32(3):135-40

20. Page M, Wilhelm MS. Postpartum daily stress, relationship quality, and depressive symptoms. Contemp Fam Ther. 2007;29:237-51.

\section{Corresponding author}

Edyta Gałęziowska

Department of Oncology and Environmental Health, Faculty of Health Science, Medical University of Lublin

4-6 Staszica St., 20-081 Lublin

E-mail: edyta.galeziowska@umlub.pl 